\title{
Walter Benjamin e a história messiânica: contra a visão histórica do Progresso
}

\author{
Maria João Cantinho \\ Universidade Nova de Lisboa
}

\begin{abstract}
Resumo: Uma das problemáticas essenciais do pensamento benjaminiano é, precisamente, a questão da história. Numa época em que a tonalidade dominante é a ameaça da guerra e a destruição das ideologias, dos valores e ideais clássicos, em nome de uma desenfreada visão progressista e continuista da história humana, é preciso despertar do pesadelo da catástrofe da história. É esta que é responsável pela dissolução do conceito de experiência, alienando o homem e deixando-o desamparado e entregue ao vazio da experiência do choque, à fragmentação da narração e à perda da tradição. Recorrendo à tradição judaica da história, pensando e reconfigurando conceitos que lhe são intrínsecos, como o de catástrofe, messianismo, redenção, rememoração, Benjamin constrói (tal como Rosenzweig, Scholem e Bloch) uma teoria que possa operar uma desconstrução da continuidade da história, valorizando o objeto histórico, destacando-o do fluxo e salvando-o da catástrofe. Trata-se, assim, de um método destrutivo e violento, mas que visa restaurar uma visão da história que seja capaz de reparar as injustiças e o sofrimento humano. Mais do que histórica e temporal, essa nova ordem inscreve o sagrado na ordem profana, redimindo o acontecimento histórico e salvando-o no instante dialético.
\end{abstract}

Palavras-chave: Messianismo. História. Linguagem.

\begin{abstract}
O que foi, o que é e o que será, a história do passado e do futuro, as coisas que tive e as que terei, tudo isso nos aguarda num qualquer lugar desse labirinto tranquilo.
\end{abstract}

Jorge Luís Borges, Nove Ensaios Dantescos.

Na perspectiva da história que o jovem Benjamin ${ }^{1}$ pensou, a partir de 1914, ao redigir textos como "A Vida dos Estudantes", "Romantik", entre outros, aquilo que define e estrutura o horizonte de sentido não são as épocas nem as finalidades da concepção historicista, mas $\operatorname{sim}$ o desenvolvimento "cultural-espiritual" da humanidade, ${ }^{2}$ que tenta superar o relativismo e a crise dos valores. É, sobretudo, no seu texto "A Vida dos Estudantes" que melhor se reflete a sua própria experiência enquanto jovem estudante e intelectual integrado no seio das novas correntes pedagógicas e educativas e onde melhor se acede à sua perspectiva da história - tomando a primeira fase da sua obra e das linhas de pensamento que o orientavam, desde a presença do 
pensamento kantiano (e neo-kantiano), de Nietzsche, dos primeiros românticos e de Wynecken.

É já na carta que Benjamin escreve a Carla Seligson, datada de 4 de Agosto de $1913,{ }^{3}$ anunciam-se os motivos que antecipam a filosofia da última fase de Benjamin, isto é, uma visão metafísica da história, que se opõe ao historicismo e, ainda, à crítica ao historischer Sinn, ao senso histórico. Nessa carta, a sua perspectiva da visão metafísica da história apresenta-se à luz da relação do homem com a comunidade e com a moralidade. ${ }^{4}$ Estabelecendo uma relação dessa carta com o texto "A vida dos Estudantes", podemos compreender melhor como Benjamin já antecipava claramente essa visão messiânica ${ }^{5}$ de que fala. Na verdade, Benjamin representa já o "progresso" como uma forma da temporalidade mecânica e vazia, incoerente. ${ }^{6}$ Nesse sentido, Benjamin coloca-se no coração da problemática da história pós-hegeliana, do mesmo modo que Rosenzweig ${ }^{7}$ o havia feito e também Bloch e Scholem, posteriormente. Isto é, ele opõe-se à ideia de uma visão otimista da história que pode ser concebida como uma marcha permanente em direção ao progresso.

Relativamente à história vista à luz do progresso, cada um deles opõe uma modalidade diferente, mas sempre insistindo na descontinuidade da história e sem a homogeneidade que lhe era conferida por aquela visão, na medida em que já não era possível a indiferença face às grandes mudanças ocorridas no século XX. Se a Primeira Guerra Mundial foi o traumatismo original que deu origem a uma série de transformações, a mais direta e nefasta consequência é a perda de uma ideia de civilização fundada sobre a crença num Logos capaz de instaurar a ordem, num mundo regulado pela razão. ${ }^{8}$ Por outro lado, também a perda e o desabamento de um mundo regulado pela transmissão da tradição e da memória coletiva, de geração em geração, ${ }^{9}$ arruinado pela guerra, põe em causa um modelo antigo que havia garantido sentido à experiência humana.

Tanto Rosenzweig, quanto Benjamin e Scholem identificaram este modelo de "falsificação da realidade" na ideologia do progresso, que excluía "da memória coletiva todas as falhas, as regressões, todos os fracassos que pontuavam o desenrolar da história", ${ }^{10}$ pois mesmo a própria versão hegeliana - que era, a seus olhos, a mais rica da filosofia do progresso elogia o "triunfo do positivo". É a guerra, ${ }^{11}$ vivida como acontecimento radical, que se torna irredutível à história do sentido e denuncia o 
absurdo de toda a teodiceia imanente à história, obrigando o pensamento a confrontarse com a perda de sentido de uma visão cumulativa e quantitativa da história, no sentido de uma perfeição final. Obriga-nos, também, a confrontarmo-nos com a própria realidade, isto é, "como uma justaposição de momentos qualitativamente diferentes uns dos outros e que não se deixam totalizar".

A fissura do tempo catastrófico irrompe e dá-nos a ver a falsa continuidade do progresso, a falsa continuidade da razão histórica, a falsa totalidade. Doravante, só a experiência do imprevisível acontecimento histórico é tomada como certeza, o que antes se apresentava em triunfo histórico aparece como fracasso e esperança perdida num otimismo histórico intrínseco à visão progressista da história. Mais do que apenas reflexão teórica, Benjamin sentiu na própria pele o desabar da crença no progresso e a falência desse paradigma, conduzindo-o a uma visão pessimista da própria história e da tradição.

Gostaríamos, no entanto, de afirmar de modo explícito que, apesar do entendimento benjaminiano da falência desse paradigma, que ele percebeu claramente, não é senão num período posterior ${ }^{12}$ que ele irá desenvolver uma verdadeira reflexão sobre a história, nomeadamente num período tardio em que redigirá "Sobre o Conceito de História" 13 (1940). Porém, muito cedo, Benjamin compreendeu o desaparecimento, não apenas da homogeneidade do "fio" da história, como a dissipação da ideia de continuidade e, ainda, a possibilidade de uma causalidade necessária e racional que regularia o seu curso.

Todavia, apesar do pessimismo crescente na sua época, o fim da crença numa história vista como progresso não conduziu à perda da ideia de esperança na história. $\mathrm{O}$ que se impõe é a mudança de uma visão da história em alternativa e é precisamente nas ruínas do paradigma da Razão histórica, que a esperança se anima e conquista um novo fôlego. É nas cinzas do Progresso que a chama da utopia se ergue. A utopia, como afirma Mosès,

que não pode mais ser pensada como a crença no acontecimento necessário do Ideal no termo mítico da história, ressurge - através da categoria de Redenção - como a modalidade do seu acontecimento possível a cada instante de tempo. No modelo de um tempo aleatório, aberto a todo o momento à erupção imprevisível do novo, a realização eminente do ideal torna-se pensável, como uma das possibilidades oferecidas pela insondável complexidade dos processos históricos. ${ }^{14}$ 
Esta nova concepção da história era irredutível ao modelo teleológico da história, que era a sua característica essencial na época. Mas é precisamente no quadro desta crise da civilização ocidental e da concepção da história como progresso que se pode compreender o gesto de advertência de Benjamin. ${ }^{15} \mathrm{Na}$ opinião de Mosès, Benjamin, pela sua condição cultural e pelo contexto em que se encontra integrado, volta-se para a experiência judaica da história, "para descobrir uma dimensão radicalmente diferente da consciência histórica e da sua dimensão utópica. O messianismo judaico, com efeito, sempre teve de confrontar-se com a experiência histórica da catástrofe, da decepção e do fracasso."16

A esperança messiânica judaica nada tem que ver com as etapas de uma finalidade histórica, mas, ao invés, aloja-se nas fissuras da história, onde ela se deixa ver na sua fragilidade, na sua descontinuidade, lutando por salvar no presente o que foi o passado. Em Benjamin, como se há de ver, são as "imagens dialéticas" que tentam levar a cabo essa salvação do passado e da história, no tempo do presente, tal como o mostrará o Livro das Passagens. ${ }^{17}$

Walter Benjamin, no texto "A Vida dos Estudantes", opõe a imagem da utopia como um "estado bem determinado", o "estado imanente da perfeição" (den immanenten Zustand der Vollkommenheit), que ele identifica no mesmo encadeamento lógico ao ponto focal (Brennpunkt), em redor do qual toda a história parece recolher-se em estado de repouso. ${ }^{18}$ Este "ponto focal" representa o fechamento, o ponto de paragem do tempo, mas ao mesmo tempo, também, o ponto de abertura para a utopia messiânica. Apresentando-se esse ponto como "Reino messiânico" ou "como ideia revolucionária no sentido da Revolução Francesa de 1789”, configura-se como o ponto de reunião, também, entre o messianismo e a utopia comunitária. ${ }^{19}$ A sua realização não é uma abstração, mas sim uma tarefa ${ }^{20}$ e cabe ao homem (ao indivíduo ativo) a fundação de um tal "estado imanente de perfeição, ${ }^{21}$ pelo reacender da centelha messiânica ou da "frágil força messiânica" (eine schwache messianische Kraft) ${ }^{22}$ que cabe a cada um de nós. É extremamente importante marcar aqui dois aspectos de que nunca podemos esquecer-nos, para evitar armadilhas.

Embora se procure estabelecer aqui um fio condutor que possa interligar os textos "A vida dos estudantes" (1915) e "Sobre o conceito de história" (redigido em 1940, mas publicado apenas postumamente e graças à corajosa insistência de Hannah 
Arendt), os contextos políticos e sociais nos quais se inserem os textos são diferentes. Entre 1915 e 1940, Benjamin alterou significativamente os seus conceitos, reconfigurando-os, cedeu às grandes forças intelectuais da sua época que o influenciaram inegavelmente, daí a necessidade de uma leitura particularmente rigorosa dos textos. No entanto, há aspectos - e são esses que procuramos frisar aqui - que se mantêm como temas e problemas recorrentes e constantes. A questão da história e da temporalidade como uma tarefa messiânica e as noções que lhe são intrínsecas (a justiça, a ética, a moralidade), bem como a forte convicção benjaminiana contra a visão da história como progresso, mantêm-se praticamente inalteradas e essa é a nossa preocupação: a de demonstrar as preocupações com que, desde sempre, o pensamento benjaminiano se confrontou.

Se no texto "A vida dos estudantes", ainda não aparece a importância decisiva do materialismo dialéctico ${ }^{23}$ na perspectiva da história, a ideia de uma tarefa histórica que deve conduzir a um estado imanente de perfeição é já claramente desenvolvida e anunciada. De acordo com Tamara Tagliacozzo, Benjamin bebe certamente no messianismo do filósofo neo-kantiano Hermann Cohen, para quem o messianismo se constitui como "tarefa infinita" 24 da história, perspectiva na qual a "justiça é igual à santidade, isto é, à realização da moralidade, que é um atributo do messias." 25 Ideia metafísica, moral e ideal que se projeta na dimensão do futuro da história - não numa vida supraterrestre - apresenta-se, assim, como uma promessa que alimenta a esperança na existência individual humana. Uma promessa como vemos na tese XVII, ${ }^{26}$ de caráter eminentemente político, constituindo-se como "ação política revolucionária e destrutiva." ${ }^{27}$ No entanto, a concepção de Cohen relativamente ao messianismo como atitude ética é claramente herdada pelo jovem Benjamin.

Já aqui se apresenta a imagem da história como um acabamento que é recolhido numa iluminação momentânea ou instantânea, o tempo a que ele chamará também, no Livro das Passagens, o Agora (Jetztzeit), no qual se recolhe, na imanência do presente, a imagem do estado da perfeição moral, da redenção. É este tempo, o do instante messiânico, que configura a imagem utópica, onde é representada uma nova realidade metafísica, mas também uma nova realidade política, ${ }^{28}$ ética e de conhecimento da perfeita actualidade, num tempo vindouro que pode irromper a cada instante, o instante 
messiânico ou aquilo a que Benjamin chamará mais tarde "a estreita porta por onde chegará o Messias."29

Essa era a razão, precisamente, pela qual todo o futuro ganhava o seu sentido, pois era a imagem utópica e redentora do instante messiânico que conferia ao tempo a sua plenitude, como tempo cheio, messiânico. Nunca homogêneo e contínuo, à maneira da visão historicista do progresso:

Certamente, os adivinhos que interrogavam o tempo. Quem tem em mente
esse facto, poderá talvez ter uma ideia de como o tempo passado é vivido
como rememoração: nem como vazio, nem como homogéneo. Sabe-se que
era proibido aos judeus investigar o futuro. Ao contrário, a Torah e a prece
ensinam-se na rememoração. Para os discípulos, a rememoração
desencantava o futuro, ao qual sucumbiam os que interrogavam os adivinhos.
Mas nem por isso o futuro se converteu, para os judeus, num tempo
homogéneo e vazio. Pois, nele, cada segundo, era a porta estreita pela qual
podia entrar o messias. ${ }^{30}$

Se, como diz Walter Benjamin na tese XVIII B, a rememoração era o que conferia o sentido à história e ao passado, é a imagem utópica (e revolucionária) do "Messias que há-de-vir" que garante também a plenitude ao futuro, convertendo-o em promessa e algo que pode ser alcançado. Dizemos assim, já que falar em "espera messiânica", como é habitual no judaísmo, conduz-nos a um messianismo passivo, retirando-lhe esse caráter de tarefa ativa.

O tempo nunca aparece, assim, à luz da concepção judaica, como homogêneo e vazio, mas sempre pleno: ora como rememoração (em relação ao passado e atualizandoo) ora como promessa (relativamente ao futuro). Se a rememoração resgata o passado, como haveremos de ver mais detalhadamente, reatualizando a tradição, essa reatualização é sempre sacralizada e descontínua e nunca aparece a temporalidade na sua forma vazia e homogénea. A concepção do tempo messiânico opõe-se à concepção físico-matemática, o tempo infinito que é precisamente o fundamento da ideia da história como progresso infinito. A distinção entre a visão histórica, do ponto de vista do progresso e do ponto de vista judaico-messiânico, decorre certamente da própria concepção da temporalidade que lhes é intrínseca. ${ }^{31}$

Retomando o texto "A vida dos estudantes", em que Benjamin fala de um "estado final" em que os elementos não seriam identificados, segundo ele, numa "tendência informe de progresso". Ao invés, este "estado final" (Endzustand) é constituído numa outra ordem de sentido: 
Os elementos do estado final não se situam como uma informe tendência progressista, mas, pelo contrário, sob o aspecto de obras e ideias alojadas no próprio coração do presente; e trata-se, precisamente, das mais ameaçadas, mais depreciadas e ridicularizadas. A tarefa do historiador consiste em dar uma imagem absoluta deste estado de acabamento ainda imanente, em tornálo visível e em fazê-lo reinar no próprio presente. ${ }^{32}$

Ameaçadas pelo risco do efémero, certamente, pela arrogância típica de uma época que julga tudo saber por fundamentar todo o conhecimento na especialização científica e através da massificação do pensamento. É bem a valorização do detalhe e do individual, da criação solitária e corajosa, que aqui nos parece estar em causa, numa aversão clara aos ideais que cristalizam uma época e a petrificam no sistema.

A simultânea presença, no pensamento de Benjamin, de uma "desconstrução" da história do ponto de vista do progresso, paralelamente à construção de uma nova perspectiva, onde o tempo aparece como "tempo cheio" é algo que se desenha claramente, também, no texto "A metafísica da juventude" ("Metaphysik der Jugend"). ${ }^{33}$ Esse texto, composto no final de 1913 e início de 1914, contém como elementos essenciais uma concepção do tempo messiânica e o esboço de uma concepção da linguagem que se desenvolverá mais tarde, em “Sobre a linguagem". É neste último texto que a concepção messiânica da linguagem alcança a sua maturidade. ${ }^{34} \mathrm{O}$ conceito de tempo messiânico é a base do texto "O Diário" ("Das Tagebuch"). ${ }^{35}$ Aí, Benjamin refere-se à dimensão espiritual da tradição, remetendo para a possibilidade messiânica da redenção. É o silêncio e a linguagem - como essencial e não comunicativa - que se constituem como o património deste tempo messiânico. ${ }^{36}$ Este tempo é o tempo "juvenil, imortal", 37 que Benjamin contrapõe ao tempo mecânico e irreversível. ${ }^{38}$ É no horizonte de uma atemporalidade (Zeitlosigkeit), ${ }^{39}$ que confina com a "imortalidade do pensamento e da acção" que se pode conceber a redenção messiânica, irrompendo no profano, como catástrofe destrutiva. Mas a vinda do Messias é o acontecimento que comporta consigo, no gesto destrutivo, a fundação da justiça.

$\mathrm{O}$ "Eu" ${ }^{40}$ que escreve no diário fala do tempo "imortal", o tempo da grandeza, o tempo completo do silêncio, da linguagem, o tempo religioso do "crente", ${ }^{41}$ que escreve nos intervalos [Abständen]. Nesses intervalos, o tempo recolhe-se como o tempo puro e cheio, messiânico: "Mas, por último, pelo nascimento do tempo imortal, o tempo não acontece mais. Acontece o intemporal, todas as coisas se recolhem nele, são presas dele. Omnipotente vive no intervalo, no intervalo (no silêncio do diário) acontece ao Eu o seu 
tempo próprio, o tempo puro." (p. 98). Em “Der Ball” (“O Baile”), a última parte deste texto poético e inspirado, o tempo de que fala o autor é "o tempo nascendo na muda melodia dos intervalos" ${ }^{2}$ e é através desta melodia que se abre o espaço redentor, o espaço da dança dos corpos $\operatorname{castos}^{43}$ - simbolizando a pureza da Ideia moral. Benjamin evoca aqui a imagem nietszchiana do funâmbulo de Zaratustra, ${ }^{44}$ do homem que "caminhasse sobre uma corda esticada ao alto, através da noite." 45 Só na música do tempo cheio - entenda-se, messiânico - a noite se ilumina e irradia, superando o tempo. Da noite surge, assim, o dia redentor, mediante a música da promessa redentora, a promessa da justiça e do acabamento da história.

A guerra, como já referimos, pôs à vista as falhas e as fissuras deste paradigma do conhecimento e da teoria da história. É necessário, isto é, urgente, repensar um novo modelo da história e do seu conhecimento, que, não apenas responda às questões suscitadas pela história, como seja igualmente eficaz contra a decadência da ideologia do progresso, que já se adivinha nas falhas do capitalismo e da sociedade moderna. Por um lado, Benjamin confronta-se com um pessimismo crescente - que revela a ineficácia da ideologia do progresso - por outro, com um perigoso e falso optimismo crescente nas hostes de uma Europa empobrecida pela guerra e que vê nas ideologias reaccionárias, no pré-fascismo e no capitalismo emergente a resposta mais sedutora para os seus problemas. Visionário, o jovem Benjamin esteve sempre na dianteira da sua época, diagnosticando o mal-estar generalizado que crescia lentamente e se insinuava no coração de uma Europa atingida pela catástrofe. Essa catástrofe dizia respeito, não apenas à face mais visível da guerra, mas igualmente à ameaça (que vinha a desenvolver-se desde meados do século XIX) da perda de experiência (Erfahrung), no seu sentido mais autêntico.

É a essa ameaça do desaparecimento da tradição (e da transmissão da tradição), acarretada pelas grandes mudanças da sua época, que o pensador lúcido tenta contrapor novos modelos (retomando o pré-romantismo) de compreensão do conhecimento da realidade histórica. Avesso à lamentação e empenhado numa perspectiva crítica do conhecimento, um racionalista feroz, mas não cego, Benjamin luta por resgatar a experiência e conferir-lhe um novo sentido, recorrendo a uma configuração outra do pensamento: o pensamento judaico-messiânico. Nesse sentido, Benjamin vai mais 
"longe" que outros pensadores judaicos, pois, ainda que consciente da sua herança cultural, não cede ao facilitismo da teologia ou da mística. ${ }^{46}$

Veja-se o esforço que ele realiza, mantendo à distância as soluções que seduziram Scholem e Rosenzweig. É no esforço constante, no solo do racionalismo crítico (que tão firmemente bebeu em Platão e Kant) que Benjamin desenvolve o seu pensamento. Podemos falar, em Benjamin, de um pensamento solitário e irredutível a qualquer corrente, podemos falar de um pensamento puro e radical, ético e fiel apenas a si próprio. Neste sentido, também, podemos falar de um pensamento único, verdadeiramente revolucionário e animado pela chama da utopia messiânica. Mas esta utopia messiânica, sob a forma das "imagens utópicas", não é uma abstracção vaga, mas sim algo que confere o seu sentido prático e concreto, um sentido verdadeiramente político e actual. Não é a imagem teológica de um Messias Redentor, aquele por quem o povo judeu espera passivamente, na esperança da salvação, mas sim a possibilidade real e imanente da fundação de um estado de perfeição ${ }^{47}$ entre os homens, no palco da história, onde a justiça desfere a sua sentença final.

Não é de uma atitude especulativa e teórica que tenha por função reanimar a esperança no coração do povo judeu, de que falamos aqui, como na teologia hebraica, mas sim de um projecto onde o messianismo aparece como força concreta, revolucionária e destrutiva, interrompendo o curso da história e resgatando-a, através das imagens utópicas.

Se, como diz nos Benjamin na sua bela fórmula nas Afinidades eletivas de Goethe, "Para os desesperados somente nos foi dada a esperança", ${ }^{48}$ não é, no entanto, esta esperança (passiva) de que ele nos fala. O que ele tem em mente é um verdadeiro projeto político e revolucionário, em que cada homem é responsável pela "parcela messiânica" que lhe é transmitida pelas gerações precedentes. Nesse sentido, cabe-lhe a ele perpetuar essa herança da tradição e transmiti-la, lutando por resgatar o passado do seu esquecimento, criando o espaço "onde pode dançar", ao som da melodia do tempo messiânico. $\mathrm{O}$ espaço da dança, crivado de perigos e de ameaças, solitário (e não é por acaso que Benjamin evoca a imagem do funâmbulo de Nietzsche, que é atirado para a morte pelo palhaço, a figura da contingência) é o espaço da perfeição e do ideal (que ele ainda evoca romanticamente na "Metafísica da juventude"), o lugar ou o topos da 
revolução e da restituição da justiça. O topos, também, da história tomada como um processo ativo e eminentemente restaurador.

Assim, é bem no coração desta articulação entre messianismo e revolução que situamos a plataforma da perspectiva histórica de Benjamin, que o autor contrapõe à "informe tendência progressista". São estes, também, os temas do debate que ele perseguirá ao longo de toda a sua vida. Mas qual a relação existente as "duas imagens utópicas", o reino messiânico e a revolução? Na nossa opinião, existe um texto que procura responder a essa relação e que é o breve Fragmento teológico-político ("Theologisch-politisches Fragment"). ${ }^{49}$

De acordo com Tiedemann e com Gérard Raulet, ${ }^{50}$ a gênese desse texto terá tido lugar em 1920. Visivelmente marcado ${ }^{51}$ pela leitura de Geist der Utopie, de Ernst Bloch, Benjamin redige o "Fragmento teológico-político", imerso no fervilhamento cultural e político da sua época. A outra leitura fundamental na qual podemos entender o contexto do texto de Benjamin é, sem dúvida, o "Tratado teológico-político", de Spinoza. Em ambos, o fragmento e o texto de Spinoza, existe uma recusa da teocracia, sendo a reflexão de Spinoza verdadeiramente notável na sua época e reconhecendo a liberdade humana como um valor inalienável. Como linha de força essencial, Baruch Spinoza repensa a relação entre autoridade civil e autoridade eclesiástica e concede a primazia à liberdade individual, numa clara recusa da teocracia. Por outro lado, a obra de Bloch vai descrever a renovação espiritual da jovem geração judaica e, ele próprio invoca a tradição spinozista e a sua síntese do pensamento cabalista e o das matemáticas e da filosofia da natureza. ${ }^{52}$

Nesse contexto preciso, podemos dizer que o "Fragmento teológico-político" se articula de acordo com passagens ou etapas perfeitamente lógicas. A primeira etapa distingue radicalmente entre a temporalidade do evento histórico e a do acontecimento messiânico. Enquanto o evento histórico se caracteriza pela tensão e espera, pela sua relação ao messiânico (Beziehung auf das Messianische $)^{53}$ : desta forma, ela constitui-se em teleologia pela relação que estabelece com o acontecimento messiânico que espera. No segundo parágrafo, Benjamin diz: "A relação desta ordem ao messiânico é um dos ensinamentos essenciais da filosofia da história", isto é, é desta relação que nascem as teleologias e teodiceias. Mas esse telos é uma falsa consciência - Benjamin vai mais longe, dizendo que essa é uma compreensão mística da história. Porque, se o Messias 
pode pôr fim à espera, então a sua vinda significará uma mudança na ordem da temporalidade que "varrerá" o tempo histórico, ao mesmo tempo que o cumpre.

Existe, assim, uma completa incompatibilidade entre as duas temporalidades e a pretensão de nos referirmos à vinda do Messias em termos históricos é o maior dos equívocos, na óptica de Benjamin. É por esta razão que “o reino de Deus não é o telos da dinâmica histórica; ele não pode ser posto como objectivo. Considerado do ponto de vista histórico, ele não é objectivo (Ziel), mas termo (Ende)." ${ }^{54}$ Nesse sentido, toda a teocracia tem um significado religioso, apenas, e nunca político - e esse é o grande mérito que Benjamin reconhece a Bloch. ${ }^{55}$ Também nesta ótica, Benjamin é mais radical que Bloch, que não renuncia à finalidade apocalíptica e judaica da história.

Se o Messias põe fim à história, então ele não pode ser um objectivo e, pela mesma razão, não poderia jamais fundar a ordem profana. É neste sentido que a teologia não poderia fundar a política. E a ordem profana não pode (ou não deve) ser teocrática, por carecer de legitimação. A teocracia profana constitui, na opinião de Benjamin, uma forma equívoca e é por isso, precisamente, que ele se vai esforçar por definir a maneira particular como a ordem profana se pode relacionar com a ordem messiânica.

Como Benjamin afirma, no início do segundo parágrafo, a espera messiânica toma, na ordem profana, a forma da procura da felicidade: “A ordem do profano deve edificar-se sobre a ordem da felicidade. A relação dessa ordem com o elemento messiânico é um dos ensinamentos essenciais da filosofia da história."56 Significa tal que a dimensão da espera messiânica é fundamental e constitui o ponto fulcral para o qual se orienta a filosofia da história. Mas, como reconhece, também, esta é "uma concepção mística da história" e não isenta de problematicidade. Pois, se as duas temporalidades, histórica e messiânica, são radicalmente incompatíveis, isso coloca-nos uma dificuldade. Se a primeira, a temporalidade histórica, visa um objectivo, um telos, ela é linear e horizontal - regendo-se pela continuidade - enquanto a outra é vertical.

\footnotetext{
Se se representa por uma flecha o objetivo para o qual se exerce a dynamis do profano, por uma outra flecha a direção da intensidade messiânica, seguramente a busca pela felicidade da livre humanidade tende a se desviar dessa orientação messiânica. ${ }^{57}$
}

A primeira é uma dinâmica, enquanto a segunda é uma intensidade. As forças são completamente divergentes, pois a direção é totalmente diferente. Se a temporalidade da história se define de forma horizontal, a intensidade messiânica é uma 
força vertical. Todavia, é possível ver o problema desta maneira, como explica Gérard Raulet. 58 "Da mesma maneira que uma força, pela sua direcção, pode contribuir para uma força orientada no sentido contrário, também a ordem profana da realidade profana pode favorecer o advento do reino messiânico". E esta é precisamente a forma como Kant ultrapassa esta contradição aparente entre os factos e o sentido da história, num esforço para racionalizar o problema, como ele o faz precisamente na sua teleologia, sublinha ironicamente Raulet.

Na sua óptica, tal como Spinoza, Benjamin pretende "racionalizar" a teleologia. Isto é, antes de mais, não esqueçamos que Benjamin é ferozmente racionalista e procura, precisamente, encontrar um sentido da história numa concepção diferente da ideologia do progresso. Alheio às concepções místicas da história, não vê senão a possibilidade de racionalizar o que lhe aparece como contradição, como a melhor forma de ultrapassar aquilo em que ele considera que Kant falhou. ${ }^{59}$ É em Spinoza que Benjamin vê a melhor forma de "racionalizar a teleologia kantiana". E ela consiste essencialmente em "pôr fim, sob certas condições, à incompatibilidade das duas ordens, a ordem profana e a ordem messiânica, e em estabelecer entre elas uma sinergia ou uma dialéctica." ${ }^{\text {,0 }}$ A questão permanece: como conciliar o que na sua natureza é inconciliável? Se a natureza da perspectiva profana se orienta para a procura da felicidade, "a intensidade messiânica do coração, de cada indivíduo no seu ser interior, adquire-se através da infelicidade, no sentido do sofrimento", isto é, numa orientação totalmente inversa.

Desta forma, a aniquilação e a destruição da ordem profana constituem uma exigência, pois a única forma de a felicidade profana aceder ao eixo messiânico é aniquilando-se, abolindo o eixo profano: "Porque, na felicidade, tudo o que é terrestre aspira à sua aniquilação, mas é somente na felicidade que esta aniquilação lhe é prometida." ${ }^{61}$ Ou seja, a ordem profana não pode atingir o seu objectivo (telos) sem lhe pôr um fim (Ende). Assim, dizer felicidade e abolição da ordem profana significa falar do mesmo, ainda que aparentemente se contradigam. ${ }^{62}$

Do mesmo modo que existem duas ordens, isto é, a ordem messiânica e a ordem profana, existem também duas formas de restitutio in integrum (apokatastasis). E, para Benjamin, a restitutio in integrum profana não pode tomar outra forma senão o desaparecimento (Untergang), pois a felicidade apenas se cumpre nesse 
desaparecimento. Ela é a forma particular pela qual a ordem profana acede à eternidade (Ewigkeit eines Untergangs). ${ }^{63}$ Portanto, o que é abolido, assim, na eternidade, é a totalidade espacial e temporal do mundo. ${ }^{64}$

A aniquilação (que aparecerá como uma constante no Livro das Passagens, nas referências que Benjamin faz à construção do conhecimento do objeto histórico através das "imagens dialéticas") refere-se à interrupção do fluxo contínuo e à dissipação da ordem linear do tempo. É pela abolição e destruição do fluxo contínuo, que rasga o tecido da temporalidade da história - a temporalidade profana, também - que se instaura uma nova realidade evanescente. A dinâmica transforma-se, através do aniquilamento, em ritmo; ritmo de um eterna dissolução na eternidade. Eterno, no sentido em que a ordem profana não deixará de tentar abolir-se a si própria, para aceder ao que procura: a eternidade. Assim, a substituição do termo de dinâmica pelo de ritmo constitui uma mediação pela qual a ordem profana junta a intensidade.

Se não há nada de menos messiânico que a própria natureza, que, segundo o Genesis, é o que ela é, pode-se falar da conversão desta natureza dinâmica em ritmo, pela sua abolição ou aniquilamento. Isto é, ela deve abolir-se eternamente para "dar lugar" ao messiânico. E este aniquilamento da natureza deve ser total, pois não é possível uma meia-medida entre as duas ordens, elas são incompatíveis. Este caráter destrutivo, de abolição da natureza, ${ }^{65}$ também se encontra na sua obra $A$ Origem $d o$ Drama Barroco Alemão, que Benjamin redigirá um pouco mais tarde e referindo-se sempre ao sentido da história. No capítulo "O Saber como Emblema",66 da obra $A$ Origem do Drama Barroco Alemão, quando Benjamin se refere à alegoria como método operatório de constituição do saber, fala de uma "libertação" que ocorre "quando o profano se dissolve no sagrado" e é precisamente esta libertação - que a alegoria leva a cabo - que cria o sentido da história, "de uma teologia da história e de forma dinâmica, e não estática e no sentido de uma economia da salvação." ${ }^{\text {67 }}$ Esta abolição eterna põe fim ao eterno retorno do mesmo que é o ciclo infernal da história natural (Naturgeschichte), impede que ela reproduza ad infinitum as suas figuras.

Porém, o que nos parece mais importante ressaltar é que este caráter destrutivo do messianismo tem uma conotação prática, no sentido em que visa a abolição da Naturgeschichte para que a própria natureza se torne messiânica e não apenas espiritual. Trata-se um "programa político" que nada tem de puramente contemplativo ou 
puramente espiritual, mas sobretudo um apelo a um messianismo prático, que será o messianismo do caráter destrutivo. ${ }^{68} \mathrm{O}$ que se pretende é abolir a ordem antiga dos valores para criar uma nova ordem e é justamente isso que constitui a consciência lúcida do homem histórico, aquele que precisa de destruir para abrir novos caminhos, isto é, "ele só conhece um lema: criar espaço; apenas uma atividade: esvaziar."69 Esvaziar, varrer os destroços da história, para instaurar a autêntica história, isto é, a nova ordem messiânica, contrapondo-a à visão exaurida da história do Progresso.

Resumé: La question de l'histoire est essentielle dans la pensée de Benjamin. À une époque dominée par la menace de la guerre et de la destruction des idéologies, des valeurs et idéaux classiques, au nom d'une vision progressiste et continuiste de l'histoire humaine, il faut réveiller du cauchemar de la catastrophe de l'histoire. Celle-ci est responsable pour la dissolution du concept d'expérience, en aliénant l'homme et en le délivrant au vide de l'expérience du choc, à la fragmentation de la narration et à la perte de la tradition. En recourant à la tradition juive de l'histoire, en pensant et reconfigurant des concepts qui lui sont propres, tel comme le concept de catastrophe, de messianisme, rédemption, remémoration, Benjamin construit (comme Rosenzweig, Scholem et Bloch) une théorie que puisse opérer une déconstruction de la continuité de l'histoire, en valorisant l'objet historique, en le détachant du flux et en le sauvant de la catastrophe. Il s'agit d'une méthode destructive et violente, mais que vise la restauration d'une vision de l'histoire que soit capable de réparer les injustices et la souffrance humaine. Plus qu'historique et temporel, cette nouvelle ordre inscrit le sacré dans l'ordre profane, en rachetant l'événement historique et en le sauvant par l'instant dialectique.

Mots-Clés: Messianisme. Histoire. Langage.

\section{Referências Bibliográficas}

BENJAMIN, Walter. Briefe I, herausgegeben und mit Anmerkungen versehen von Gershom Scholem und Theodor Adorno. Frankfurt: Suhrkamp Verlag, 1966.

BENJAMIN, Walter. Gesammelte schriften, Tomo I e II, III e IV, "Der Begriff der Kunstkritik in der deutschen Romantik", "Goethes Wahlverwandtschaften", "Ursprung des deutschen Trauerspiels", "Das Kunstwerk im Zeitalter seiner technischen Reproduzierbarkeit", "Die Schulreform, eine Kulturbewegung", "Charles Baudelaire. Ein Lyriker im Zeitalter des Hochkapitalismus", "Über den Begriff der Geschichte", unter Mitwirkung von Theodor Adorno und G. Scholem, hrsg. von Rolf Tiedemann und Hermann Schweppenhaüser, Suhrkamp Verlag, Frankfurt am Main, 1972-1990.

BENJAMIN, Walter. Passagens. Trad. Irene Aron e Cleonice Paes Barreto Mourão. Belo Horizonte: Editora UFMG; São Paulo: Imprensa Oficial do Estado de São Paulo, 2006.

BLOCH, Ernst. Geist der Utopie. Frankfurt : Suhrkamp Verlag, 1918.

DERRIDA, Jacques. Force de Loi. Paris: Galilée, 1994. 
LÖWY, Michael. Avertissement d'incendie, une lecture des thèses «Sur le Concept d'Histoire». Pratiques Théoriques, Paris: PUF, 2001.

LÖWY, Michael. R. Sayre, Révolte et Mélancolie. Le Romantisme à contre-courant de la modernité. Paris: Payot, 1992.

LÖWY, Michael. Redenção e utopia: o judaismo libertário na Europa central. Trad. de Paulo Neves. São Paulo: Companhia das Letras, 1989.

MOSÈS, Stéphane. L'Ange de l'Histoire. Le Seuil, Paris, 1987.

MOSÈS, Stéphane. Système et Révélation. La Philosophie de Franz Rosenzweig,ed. du Seuil, Paris, 1982.

MÜNSTER, Arno. Ernst Bloch, messianisme et utopie. Paris: PUF, 1989.

MÜNSTER, Arno. Progrès et Catastrophe, Walter Benjamin et l'Histoire. Paris: Éditions Kimé, 1996.

NIETZSCHE. Assim Falava Zaratustra, $1^{a}$ parte, cap. 6, Lisboa: Ed. Guimarães, 1985.

RAULET, Gérard. Le Caractère Destructeur. Esthétique, Théologie et Politique chez Walter Benjamin. Paris: Aubier, 1997.

SPINOZA, Baruch. Tratado Teológico-Político. Tradução de Diogo Pires Aurélio. Lisboa: Imprensa Nacional-Casa da moeda, 2004.

TAGLIACOZZO, Tamara. Esperienza e compito infinito nella filosofia del primo Benjamin, "Storia messianica e comunità scientifica". Roma: Quodlibet, 2003.

TIEDEMANN, Rolf. "Historischer Materialismus oder politisher Messianismus?", Materialen zu Benjamins Thesen «Über den Begriff der Geschichte», Suhrkamp Taschenbuch Wissenchaft, Frankfurt, 1975.

TIEDEMANN, Rolf. Études sur la Philosophie de Walter Benjamin. Tradução de Rainer Rochlitz, prefácio de Adorno, Actes du Sud, Arles, 1987.

\section{Notas}

${ }^{1}$ No seu primeiro período, designada pela fase romântica.

${ }^{2}$ BENJAMIN. Die Schulreform, eine Kulturbewegung, Gesammelte Schriften, II, 1, p. 13-14.

${ }^{3}$ BENJAMIN. Briefe I, p. 85-90.

${ }^{4}$ BENJAMIN. Briefe I, p. 86: "Eu creio que é unicamente no seio da comunidade e a comunidade mais estreita, a daqueles que têm uma fé, que um homem pode realmente estar só: viver esta solidão onde o eu se eleva, confrontando-se com a Ideia a fim de chegar a si próprio."

${ }^{5}$ BENJAMIN. Gesammelte Schriften, II, 1, p. 75. Relembro o excerto em que ele afirma: "A tarefa histórica é a de dar forma absoluta, em toda a pureza, ao estado imanente da perfeição, de a tornar visível e de a fazer triunfar no presente. (...) Ela não é captável senão na sua estrutura metafísica, como o reino messiânico."

${ }^{6}$ BENJAMIN. Gesammelte Schriften, II, 1, p. 75: “A uma tal concepção (a do progresso) correspondem a incoerência, a imprecisão e a falta de rigor das suas pretensões em relação ao presente." 
${ }^{7}$ Cf. MOSÈS. L'Ange de l'Histoire, p. 21: "Franz Rosenzweig, Walter Benjamin, Gershom Scholem: na Alemanha dos anos 20, estes três autores elaboraram, cada um por seu lado, uma nova visão da história, no centro da qual se destaca a ideia de actualização do tempo histórico, dito de outra maneira (segundo a fórmula de Walter Benjamin) a ideia do tempo de agora. Tratase, nos três autores, de uma crítica da Razão histórica e dos seus axiomas, a saber: a ideia de continuidade, a ideia de causalidade e a ideia de progresso."

${ }^{8}$ MOSÈS. L'Ange de l'Histoire, p. 22.

${ }^{9}$ BENJAMIN. Gesammelte Schriften, II, 1, "Erfahrung und Armut", p. 213-219. Neste ensaio sobre a pobreza da experiência, que Benjamin redigiu ainda muito jovem, podemos notar o diagnóstico benjaminiano da crise da transmissão. Também no seu ensaio O Narrador[Der Erzähler], redigido posteriormente, numa crítica sobre o escritor Leskov, Benjamin corrobora as teses anteriores, lamentando essa perda e a alienação da experiência autêntica, cuja sobrevivência assentava na tradição oral e na narração. Mas em que consiste a tradição, na sua óptica? Podemos encontrar uma definição clara, numa carta que ele redige a Scholem, datada de 6 de Setembro de 1917, in BENJAMIN. Briefe I, p. 145: "Estou convencido de uma coisa: a tradição é o elemento no qual de maneira contínua, aquele que estuda se transforma naquele que ensina e isso em tudo o que diz respeito à educação."

${ }^{10}$ MOSÈS. L'Ange de l'Histoire, p. 22.

${ }^{11}$ Em Benjamin, a guerra é um factor muito importante, mas a própria morte de Heinle e da sua noiva, como expressão simbólica de recusa da guerra, constituiram, para ele, uma experiência devastadora.

${ }^{12}$ A sua concepção, que está presente desde o início do seu pensamento, irá conhecer contornos muito mais definidos em obras posteriores, dando corpo às intuições precoces da sua obra. Num primeiro período, o autor concentra-se muito mais sobre os conceitos de experiência e tradição, do que propriamente sobre a visão da história.

${ }^{13}$ BENJAMIN. Gesammelte Schriften, I, 2, "Über den Begriff der Geschichte", p. 691-704. Benjamin testemunhou o desaparecimento da democracia alemã, a tomada de poder por Hitler, o pacto germano-soviético, que fez dissipar todas as esperanças que ele havia depositado no comunismo.

${ }^{14}$ MOSÈS. L'Ange de l'Histoire, p. 24.

${ }^{15}$ A utopia aparece, aqui, no seu duplo modelo; se, por um lado, ela reveste um caráter teológico, reveste-se também de um caráter político, no quadro da justiça. Nunca será desajustado justapor messianismo e revolução no pensamento benjaminiano, pois o modo como a utopia surge no coração do presente é sempre sob a forma de "imagem dialéctica", que estabelece a fissura e o corte no tecido homogéneo da história, instaurando radicalmente o "instante messiânico", resgatando, à luz do presente o passado, configurando-o numa outra ordem histórica: a da constelação de imagens.

${ }^{16}$ MOSÈS. L'Ange de l'Histoire, p. 25.

${ }^{17}$ Publicada, no Brasil, sob o título Passagens.

${ }^{18}$ BENJAMIN. Gesammelte Schriften, II, 1, p. 75.

${ }^{19}$ A este propósito, cf. a obra de LÖWY. Redenção e Utopia, o judaísmo libertário na Europa central (um estudo de afinidade eletiva), p. 53. Löwy estabelece uma comparação interessante entre a perspectiva de Buber e Benjamin, que viam analogamente a relação entre comunidade e utopia, na forma de um "messianismo ativo". 
${ }^{20}$ Tal como em Martin Buber, Walter Benjamin defende a ideia de um messianismo ativo, o que significa dizer que o homem não espera passivamente a chegada do messias, mas quer "preparar o mundo para o reino de Deus", como uma tarefa de restituição da "frágil força messiânica" que cabe a cada um de nós. A ideia de uma tarefa histórica já aparece no texto A Vida dos Estudantes, como algo de concreto e a realizar: "A tarefa histórica é a de dar forma absoluta, em toda a pureza, ao estado imanente de perfeição."

${ }^{21}$ Neste estado perfeito, encontram-se alquimicamente combinados os elementos da utopia, o anarquismo, a revolução e o messianismo, articulando-se numa crítica cultural ao progresso do conhecimento puramente científico. Cf. LÖWY. Redenção e Utopia, o judaísmo libertário na Europa central (um estudo de afinidade eletiva), p. 87.

${ }^{22}$ BENJAMIN. Gesammelte Schriften, I, 2, "Über den Begriff der Geschichte", II, p. 694: "Existe um acordo secreto, marcado entre as gerações precedentes e a nossa. Somos esperados sobre a terra. Assim, como a cada geração, foi-nos concedida uma frágil força messiânica para a qual o passado dirige um apelo. Esse apelo não pode ser rejeitado impunemente. $\mathrm{O}$ historiador materialista sabe disso."

${ }^{23}$ Algo que apenas irá aparecer no pensamento de Benjamin em 1924, sob a influência de Asja Lascis, que o atrai para o materialismo dialéctico. Nessa altura, Benjamin lê História e Consciência de classe, de Luckàcs, que o marca irreversivelmente. Ainda em 1929, ele refere-se a essa obra como um dos raros livros que permanecem actuais. Em Gesammelte Schriften, III, p.171, afirma: "A mais acabada das obras da literatura marxista. A sua singularidade funda-se sobre a segurança com a qual ele tomou; por um lado, a situação crítica da luta de classes na situação crítica da filosofia e, por outro lado, a revolução, aliás totalmente madura, como a précondição absoluta, ou seja, o cumprimento e o acabamento do conhecimento teórico".

${ }^{24}$ Todavia, como ele afirmará claramente em Gesammelte Schriften, I, 3, “Anmerkungen zu Seite 691-704", tese XVIIa, p. 1231, esta tarefa é revolucionária, no sentido em que se afasta totalmente da "tarefa infinita" dos neo-kantianos. Benjamin fala, aqui, de "situação revolucionária", de "Chance revolucionária", o que confere à tarefa a novidade radical e se afasta da "tarefa infinita" dos neo-kantianos.

${ }^{25}$ TAGLIACOZZO. Esperienza e compito infinito nella filosofia del primo Benjamin, p. 75.

${ }^{26}$ BENJAMIN. Gesammelte Schriften, I, 3, “Anmerkungen zu Seite 691-704”, p. 1231.

${ }^{27}$ Ressalte-se sobretudo o caráter do messianismo como atitude revolucionária e destrutiva no texto de Benjamin A Crítica da Violência [Zur Kritk der Gewalt], in Gesammelte Schriften, II, 1, pp. 179-203. Neste texto publicado em Agosto de 1921, na revista Archiv für Sozialwissenshaft und SozialPolitik, t. 47, Benjamin refere a violência messiânica como o gesto divino de fundar a justiça. Esta violência, contrariamente à violência do direito [die rechtsetzende Gewalt], conservadora, é uma violência legítima, suportada pelo seu caráter ético e moral, pelo seu desejo de justiça [Gerechtigkeit]. Só a a violência messiânica é legitimada, no sentido em que o seu fim é o de fundar a justiça. Neste sentido, esta acção é política e revolucionária, pois cria um estado radicalmente novo. Todavia, ainda que distintas, na sua natureza e fim, a sua fronteira é muito ténue, como o diz Derrida, na sua obra Force de Loi, p. 103-104.

${ }^{28}$ Onde se pode identificar a ideia de uma restituição da justiça, fundada sobre o ideal de um pensamento libertário e anarquista, directamente ligado ao romantismo anticapitalista de Gustav Sorel, Gustav Landauer, Tolstoi e Strindberg. Ainda que, posteriormente, o materialismo dialéctico e o marxismo o influenciem decisivamente, Benjamin jamais abandonou as primeiras concepções, que se tornarão explícitas, novamente, no seu último texto: Sobre o Conceito de História. 
${ }^{29}$ BENJAMIN. Gesammelte Schriften, I, 2, "Über den Begriffe der Geschichte", p. 704: "Denn in ihr war jede Sekunde die kleine Pforte, durch die der Messias treten konnte." Benjamin alude a uma profecia bíblica da "porta das ovelhas", aquela que era tão estreita que só poderia passar uma ovelha, no livro de Neemias. O Messias viria, assim, por uma porta que daria para os fundos da igreja, inesperadamente, e não pela porta dourada e espaçosa. O instante messiânico é a "estreita passagem" (a porta estreita), tão breve quanto fulgurante, o improvável ponto onde tudo acontece, reunindo o Outrora e o Agora, numa imagem irradiante e esplendorosa que é o momento do conhecimento histórico.

${ }^{30}$ BENJAMIN. Gesammelte Schriften, I, 2, p. 704.

${ }^{31}$ BENJAMIN. Gesammelte Schriften, II, 1, "Trauerspiel und Tragödie", p. 133-137. Neste texto, Benjamin distingue claramente os dois tipos de concepção e de temporalidade que lhes são subjacentes, afirmando que o tempo que suporta a sua concepção da história não é redutível ao tempo da mecânica, recusando a visão matemática e homogénea da temporalidade enquanto suporte da história. A ideia do tempo completo, segundo Benjamin, "é a ideia histórica que domina na Bíblia e tem um nome: tempo messiânico. (...)O tempo trágico está para o tempo messiânico como o tempo completo do indivíduo está para o tempo completo de Deus."

${ }^{32}$ BENJAMIN. Gesammelte Schriften, II, 1, p. 75.

${ }^{33}$ BENJAMIN. Gesammelte Schriften, II, 1, p. 91-104.

${ }^{34}$ Sob a influência de Scholem e do contacto com o pensamento judaico-cabalista, as leituras decisivas de Hamann e de Humboldt, como se verá no capítulo referente à questão da linguagem em Benjamin.

${ }^{35}$ BENJAMIN. Gesammelte Schriften, II, 1, p. 96-101.

${ }^{36}$ BENJAMIN. Gesammelte Schriften, II, 1, p. 96.

${ }^{37}$ BENJAMIN. Gesammelte Schriften, II, 1, p. 97.

${ }^{38}$ Nunca será excessivo relembrar a distinção que Benjamin estabelece - e que já foi aqui referida - entre a concepção qualitativa do tempo infinito [qualitative zeitliche Unendlichkeit], que decorre do messianismo romântico, e para a qual a vida da humanidade é um processo de acabamento, e não apenas de devir, e o tempo infinitamente vazio [leeren Unendlichkeit der Zeit].

${ }^{39}$ BENJAMIN. Gesammelte Schriften, II, 1, p. 97.

${ }^{40}$ BENJAMIN. Gesammelte Schriften, II, 1, p. 97.

${ }^{41}$ BENJAMIN. Gesammelte Schriften, II, 1, p. 98.

${ }^{42}$ BENJAMIN. Gesammelte Schriften, II, 1, p. 101.

${ }^{43}$ BENJAMIN. Gesammelte Schriften, II, 1, p. 103-104.

${ }^{44}$ NIETZSCHE. Assim Falava Zaratustra, p. 19-21. O funâmbulo atravessa a corda que se encontra presa entre duas cordas, quando, de repente, se abre a portinhola e salta ao seu caminho "um rapaz cheio de cores que parecia um palhaço", que correu contra ele. Subitamente, lança um grito diabólico e salta por cima do outro. Este, surpreendido pela vitória do palhaço, cai da corda e estatela-se na praça, enquanto a multidão fugia.

${ }^{45}$ NIETZSCHE. Assim Falava Zaratustra, p. 104.

${ }^{46}$ É aliás essa resistência que lhe traz tantos dissabores ao longo da sua vida. A autonomia do seu pensamento não cessa de desiludir Scholem - pelo facto de Benjamin recusar a mística e a teologia judaica - como também decepciona Brecht - pela falta de radicalidade do seu pensamento político e social - e, ainda, Adorno, nas inúmeras e constantes críticas que este tece 
aos seus conceitos. Nunca suficientemente místico, para alguns, nunca suficientemente político para outros, nunca suficientemente racionalista para os restantes.

${ }^{47}$ Esse estado de que nos fala no texto A Vida dos Estudantes. Relembremos a exigência benjaminiana de tornar esse estado imanente, não apenas virtual. Cabe à história a tarefa, precisamente, de tornar esse estado imanente.

${ }^{48}$ BENJAMIN. Gesammelte Schriften, I, 1, "Goethes Wahlverwandtschaften", p. 201: "Nur um der Hoffnungslosen willen ist uns die Hoffnung gegeben".

${ }^{49}$ BENJAMIN. Gesammelte Schriften, II, 1, p. 203-204.

${ }^{50}$ RAULET. La Philosophie de l'Histoire, p. 187-194.

${ }^{51}$ Numa carta que redige a Scholem, datada de 15.09.1919, Benjamin diz: "Há uma semana que leio intensamente o livro de (Ernst) Bloch e vou talvez, oficialmente, de preferência, dizer-lhe (ao homem, não ao livro) assinalar o que merece elogio", in Briefe I, p. 217. Ainda que o livro não lhe agrade inteiramente, Benjamin considera a pertinência da obra, redigindo mesmo uma crítica dessa obra, como afirma a Schoen, numa carta de 5 de Dezembro de 1919 (p. 227). Durante o final do ano de 1919 e princípio de 1920, Bloch e a sua obra serão objecto de discussão entre os ele e Scholem.

${ }^{52}$ BLOCH. Geist der Utopie, p. 321.

${ }^{53}$ BENJAMIN. Gesammelte Schriften, II, 1, p. 203.

${ }^{54}$ BENJAMIN. Gesammelte Schriften, II, 1, p. 203: "Darum ist das Reich Gottes nicht das Telos der historischen Dynamis; es kann nicht zum Ziel gesetzt werden. Historisch gesehen ist nicht Ziel, sondern Ende."

${ }^{55}$ BENJAMIN. Gesammelte Schriften, II, 1, p. 203: "O maior mérito do Espírito da Utopia de Bloch é o de ter intensamente recusado toda a significação política à teocracia."

${ }^{56}$ BENJAMIN. Gesammelte Schriften, II, 1, p. 203: "Die Ordnung des Profanen hat sich aufzurichten an der Idee des Glücks. Die Beziehung dieser Ordnung auf das Messianische ist eines der wesentlichen Lehrstücke der Geschichtephilosophie."

${ }^{57}$ BENJAMIN. Gesammelte Schriften, II, 1, p. 203.

${ }^{58}$ RAULET. Le Caractère Destructeur, p. 191.

${ }^{59}$ É, aliás, nesse sentido que caminham todos os seus esforços, claramente visíveis no seu texto Sobre o Programa de uma Filosofia Vindoura, como veremos no capítulo seguinte. Trata-se, não apenas de ver o que falhou na concepção da história kantiana, como também no seu conceito de experiência [Erfahrung]. É esse esforço de superação crítica do pensamento de Kant e de retoma dos conceitos do primeiro romantismo que guia esta primeira fase do pensamento do autor.

${ }^{60}$ RAULET. Le Caractère Destructeur, p. 191.

${ }^{61}$ BENJAMIN. Gesammelte Schriften, II, 1, p. 204.

${ }^{62}$ Mais tarde, em 1937, Benjamin manterá uma forte polémica com Horkheimer, justamente a propósito da questão da felicidade. Cf. BENJAMIN. Gesammelte Schriften, II, 3, "Anmerkungen zur Seite 465-505", p. 1338. Trata-se de saber se a infelicidade é irreversível ou se a felicidade é, por natureza, o inacabado. Benjamin responder-lhe-á, citando dois versos de Ibsen: "A felicidade não nasce senão da perda/Só é eterno o que é perdido." [Glück wird aus Verlust geboren, /Ewig ist nur, was verloren]. 
${ }^{63}$ BENJAMIN. Gesammelte Schriften, II, 1, p. 204: "Ao movimento espiritual da restitutio in integrum, que conduz à imortalidade, corresponde uma restitutio secular que conduz à eternidade de um aniquilamento".

${ }^{64}$ BENJAMIN. Gesammelte Schriften, II, 1, p. 204: "Dieses in seiner räumlichen, aber auch zeitlichen Totalität vergehende Weltliche".

${ }^{65}$ Também neste texto Benjamin afirma, sobre a história natural (Naturgeschichte), que ela deve abolir-se para dar lugar ao messiânico, desenvolvendo a ideia final do Fragmento TeológicoPolítico.

${ }^{66}$ BENJAMIN. Gesammelte Schriften, I, 1, "Die Leiche als Emblem", p. 390 e ss.

${ }^{67}$ BENJAMIN. Gesammelte Schriften, I, 1, "Die Leiche als Emblem”, p. 390.

${ }^{68}$ BENJAMIN. Gesammelte Schriften, IV, “Der Destruktive Charakter”, p. 396-398.

${ }^{69}$ BENJAMIN. Gesammelte Schriften, IV, 1, p. 397. 